\title{
Testing greenhouse gasses in Slovakia for environmental Kuznets curve and pollution haven hypothesis*
}

\author{
Jana Kubicová \\ University of Economics in Bratislava \\ Slovak republic \\ e-mail:jana.kubicova@euba.sk
}

\begin{abstract}
The analytical focus in this paper is to determine the tenability of two theoretical concepts of environmental economics in the Slovak Republic: the hypothesis of the environmental Kuznets curve and the hypothesis of Slovakia as a pollution haven. We have chosen to focus on a few selected sources of environmental pollution in the Slovak Republic, specifically greenhouse gas emissions. First we examine the hypothesis of the environmental Kuznets curves in connection with selected greenhouse gas emissions in the Slovak Republic from the years 1993-2011. Next we analyze the possible causal relationship between the net inflows of foreign direct investment and the volume of selected greenhouse gas emissions in the Slovak Republic. The existence of an environmental Kuznets curve was not confirmed. It is also possible to make the same conclusion in the relationships of carbon dioxide, nitrous oxide, and perfluorocarbons emissions and economic growth (GDP per capita). Only in the case of methane was neither a linear nor a cubic relationship confirmed between the variables of interest. A quadratic relationship was confirmed suggesting that this is the only type of greenhouse gas where estimates indicate a relationship which follows an environmental Kuznets curve. Based on the calculated values of the Granger causality test we conclude that the volume of greenhouse gas emissions per capita in the present period and in any of the previous four periods has no effect on the amount of net FDI inflows as a percentage of GDP in the Slovak Republic.
\end{abstract}

Keywords: greenhouse gases, pollution haven, economic growth, Kuznets curve,

JEL Code: 047, Q56, Q53, F18

\section{INTRODUCTION}

At an annual meeting of the American Economic Association in 1954, Simon Kuznets, Nobel Prize winner in economics, delivered a speech entitled "Economic growth and income inequality". He presented the theory that up to a certain point, an increase in income per capita is accompanied by an increase in

The paper has been prepared in a framework of VEGA scientific research project no. 1/0238/13 Taxes and effectiveness of financial re-engineering tools to improve the performance of companies in the time of the crisis. 
income inequality. According to Kuznets, income inequality regularly rises during the early phases of economic growth, while in subsequent periods of economic development the distribution of income gradually equalizes and plateaus.

This evolution of income inequality can be explained by the concept that in the early stages of capitalism, when investments in physical capital are the most important source of economic growth, income inequality spurs economic growth as resources are allocated to individuals who save and invest the most. In contrast, in developed economies the importance of human capital rises, and income inequality can actually hinder economic growth. This is due to low income households that are situated in imperfect credit markets that do not have sufficient funds to finance high quality education. As a result, the quality of education deteriorates which consequently has a negative impact on the quality of human capital and jeopardizes economic growth in developed economies.

Consequently, with further economic growth the skew and kurtosis of income distribution are balanced more evenly. According to Kuznets, income distribution is unequal in the early stages of income growth, but with continuing economic growth and rising income, the measure of income inequality in society is mitigated (Kuznets, 1955). At a certain level of economic development when a high gross domestic product (GDP) per capita is reached, the level of income inequality no longer increases. There is also a point of inflection beyond which the measure of income inequality actually decreases.

The graph below is a curve showing the distribution of income in Great Britain as an inverted letter U, also known as a Kuznets curve. The economic development of Great Britain in the years 1996/7 and $2005 / 06$ is given as an example. In the $1996 / 7$ period the distribution of income is more significantly skewed upward with a significant peak than in the 2005/06 period (figure 1).

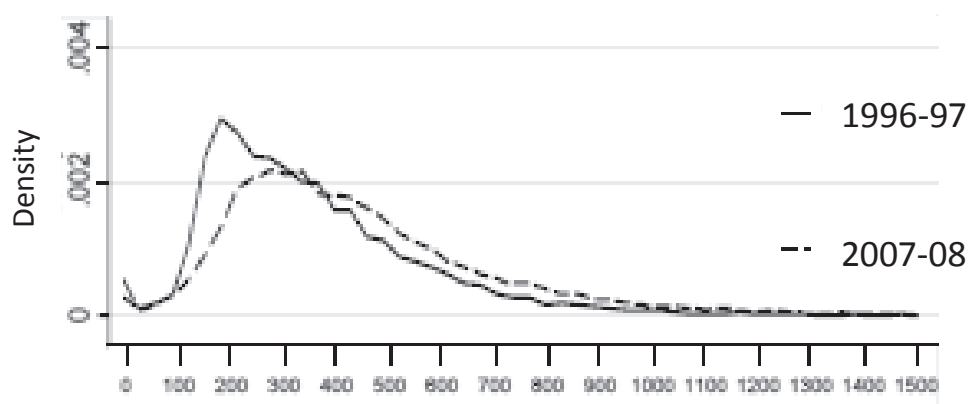

Net households equivalised income, 2007/2008 prices

Figure 1. Kuznets curves in the Great Britain

Source: Bewer, Goodman, Muriel, \& Sibieta, 2008. p. 7

Since 1991, the concept of the Kuznets curve has appeared in a new context, specifically in characterizing the relationship between economic growth and environmental pollution (Stokey, 1998), (Unruh \& Moomaw, 1998), (Yandle, et al., 2002), (Lieb, 2003), (Deacon \& Norman, 2006). In the early 1990s, discussions about the possible negative impact of economic growth on the quality of the environment arose, especially in light of the emerging free trade agreement between the United States, Mexico, and Canada (North American Free Trade Agreement, NAFTA). In their own empirical research, Grossman and Krueger 
indicated that if economic growth were to achieve a certain level, a higher income per capita is no longer associated with further deterioration of air quality, but rather with its improvement (Grossman \& Krueger, 1991). Another important study regarding the relationship between economic growth and environmental quality was conducted by Shafik et al (1992), which analyzed the relationship between GDP per capita and ten selected indicators of environmental quality. This analysis included data from 149 countries from the years 1960-1986. In regards to the annual rates of deforestation, fly ash emission, and river pollution caused by sulfur hexafluoride and fecal coliform bacteria, the results of the empirical analysis confirm the non-linear relationship between GDP per capita and pollution levels, creating an inverted U graph in all cases. Other indicators of environmental quality, such as lack of drinking water, river pollution, and a lack of urban sanitation empirically showed a significant linear monotonically decreasing relationship between GDP per capita and each specific type of pollution. In contrast, solid municipal waste and carbon dioxide emissions demonstrated a positive linear relationship between income and both indicators of pollution.

In 1999, Panayoutou (1999) gave the first detailed explanation for the relationship between the level of economic development and environmental pollution when represented by an inverted U graph. Figure 2 shows the ideal shape of the environmental Kuznets curve.

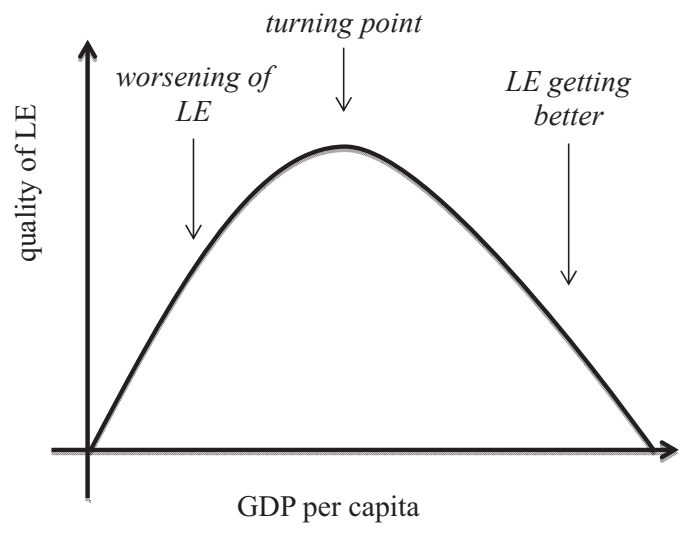

Legend: LE refers for living environment

Figure 2. Environmental Kuznets Curve

Source: (Yandle, et al, 2002, p. 3)

Another theoretical concept of environmental economics and policy is the hypothesis that countries aiming to attract foreign investment lower environmental standards and regulations, especially less developed and developing countries (Cole, 2004), (Cole, et al., 2006). If the standards of environmental regulations in a country are below a level that guarantees effective protection of the environment, or if countries fail to enforce existing environmental standards, they are known in the literature as "pollution havens", or countries that provide a haven for environmental pollution.

Since it is not possible for all countries to have uniform environmental pollution standards, Eskeland and Harrison define pollution havens more narrowly, basing their definition on the theory of comparative advantage. In a given country, if the cost of compliance with environmental standards in certain sectors is used by foreigners as their own comparative advantage, and if this country offers investors standards that 
are connected with lower costs, this country can be described as a pollution haven (Eskeland \& Harrison, 1997). However, according to Neumayer this definition of a pollution haven focuses only on the differences in the cost of compliance with environmental standards, while ignoring the reasons that lead a country to behave in such a way in the first place. Neumayer states that countries do not fail to determine and set standards that are necessary for effective protection of the environment, but rather countries fail to effectively enforce existing environmental standards because their objective is to attract foreign capital. Therefore, Neumayer uses the following definition of pollution havens for his empirical analysis: "Acountry provides a pollution haven if it sets its environmental standards below the socially efficient level or fails to enforce its standards in order to attract foreign investment from countries with higher standards or countries that better enforce their standards. In." (Neumayer, 2001, p. 148).

This paper aims to investigate presence of relationship represented by environmental Kuznets curve and pollution haven in case of selected greenhouse gases in Slovak republic. Greenhouse gases emissions pollute air and cause global warming effect. Figure 3 illustrates development of selected types of greenhouse gases emissions in Slovak republic from 1990 to 2011 and figure 4 shows share of selected types of greenhouse gasses emissions in 2011.

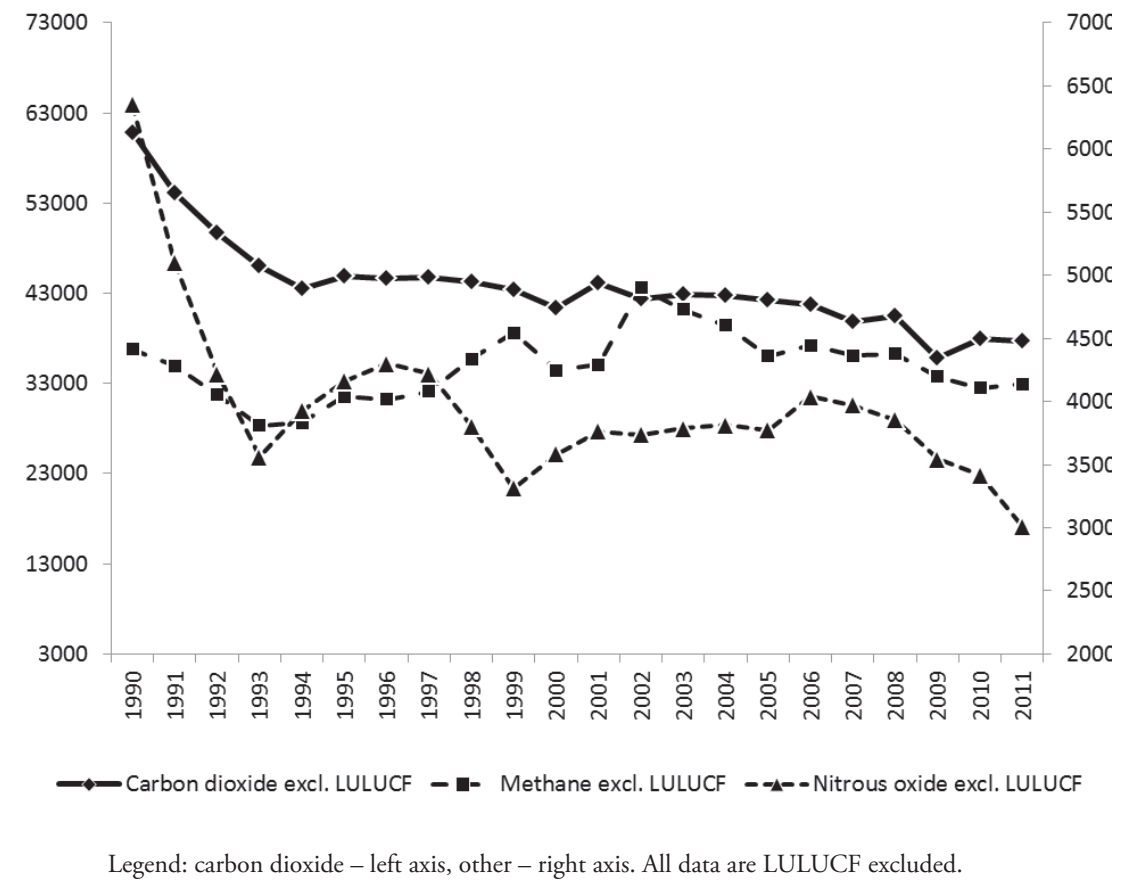

Figure 3. Development of emissions of greenhouse gasses by type of GHGs (Slovak republic, 1990-2011) Source: author, based on the OECD Environment Statistics data. 
Greenhouse gas emissions in the Slovak Republic have continuously declined since the 1990s. Since 1990, the volume of carbon dioxide emissions in the Slovak Republic dropped from 60,745.229 to 37,671.871 in 2011, or about a 38 percent reduction of the original emissions volume (Figure 3). The largest share of greenhouse gas emissions in the Slovak Republic comes from carbon dioxide (83\%) and the second largest from methane (9\%) (Figure 4).

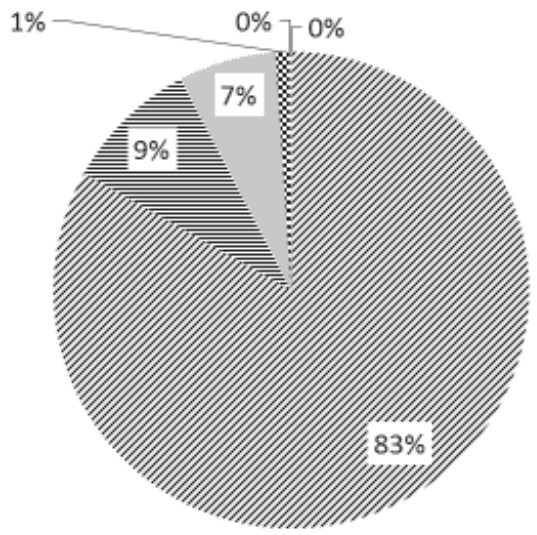

\% Carbon dioxide excl.

LULUCF

$\equiv$ Methane excl. LULUCF

Nitrous oxide excl.

LULUCF

* Hydrofluorocarbon

Figure 4. Greengasses emissions by type, Slovak republic, 2011

Source: authors own compilation based on the OECD Environment Statistics data

The analytical focus in this paper is to determine the tenability of two theoretical concepts of environmental economics in the Slovak Republic: the hypothesis of the environmental Kuznets curve and the hypothesis of Slovakia as a pollution haven. While there are many forms of environmental pollution, we have chosen to focus on a few selected sources of environmental pollution in the Slovak Republic, specifically greenhouse gas emissions.

This paper is structured as follows. The second section examines the hypothesis of the environmental Kuznets curves in connection with selected greenhouse gas emissions in the Slovak Republic from the years 1993-2011. The subject of analysis is the relationship between GDP (adjusted for inflation) per capita and the total greenhouse gas emissions per capita, e.g. emissions of carbon dioxide, methane, nitrous oxide, hydrofluorocarbons, and sulfur hexafluoride. We seek to demonstrate either that the growth in GDP per capita was proportional to the rise in each type of gas emission, or that gas emissions grew only to a certain inflection point, beyond which the volume of emissions decreased with an increase in GDP per capita. If the volume of greenhouse gas emissions dropped with the growth of GDP per capita, the hypothesis of a mutual positive relationship between economic growth and the quality of the environment would be confirmed. In the third section we will analyze the possible causal relationship between the net inflows of foreign direct investment (FDI) and the volume of selected greenhouse gas emissions in the Slovak Republic. If the volume of greenhouse gas emissions confirms the causal link with the FDI inflows, we could state that Slovakia is in fact a pollution haven. If the hypothesis of an existing environmental Kuznets curve is confirmed but the hypothesis of the Slovak Republic as a pollution haven is not, we could state that the quality of the environment has improved with economic growth and development in the Slovak Republic, and that less strict environmental policies are not used as a tool for attracting foreign investment. 


\section{GREENHOUSE GAS EMISSIONS IN THE SLOVAK REPUBLIC AND THE ENVIRONMENTAL KUZNETS CURVE}

The relationship between economic growth and environmental pollution is discussed, among other topics, in the literature dedicated to environmental protection, policy, and regulation. The consensus hypothesis is that economic growth in the early stages of development contributes to environmental pollution. However, if the economic growth reaches a certain level in conjunction with a higher GDP per capita, economic growth contributes to the improvement rather than a degradation of the environment, and is an important prerequisite. The graph of this relationship is known as the environmental Kuznets curve. According to this curve, the relationship between the growth of GDP per capita and environmental pollution is non-linear and is shown as an inverted U-shape.

The objective of the economic analysis in this section is to verify the existence of an environmental Kuznets curve in the case of selected greenhouse gas emissions in the Slovak Republic from the years 19932011.

Authors of prior research used several mathematical functions for their own analyses. One of the first studies, Shafik et al (1992) estimated parameters of three functions, the linear, quadratic, and cubic those have the following form:

$$
\begin{gathered}
E_{t}=a_{1}+a_{2} \log Y+a_{3} \text { time } \\
E_{t}=a_{1}+a_{2} \log Y+a_{3} \log Y^{2}+a_{4} \text { time } \\
E_{t}=a_{1}+a_{2} \log Y+a_{3} \log Y^{2}+a_{4} Y^{3}+a_{5} \text { time }
\end{gathered}
$$

where $E$ is the (volume) of emissions of a specific pollutant, $Y$ is the GDP per capita, $i$ is the country, and $t$ is the year, (Shafik et al, 1992). Shafik estimated the parameters of all three functional forms for each of the ten selected greenhouse gas emissions.

Another study, Stern (2004), estimates functional parameters in several studies dedicated to the verification of the environmental Kuznets curve (4)

$$
\log (E / P)_{i t}=\alpha_{i}+\gamma_{t}+\beta_{1} \ln (G D P / P)_{i t}+\beta_{2}[\ln (G D P / P)]^{2}+\varepsilon_{i t}
$$

where $E$ represents the emissions, $P$ is the population, GDP is GDP, and $\varepsilon$ is the error (Stern, 2004).

Hercegová et al (2012) estimated the functional relationship between carbon dioxide emissions and sulfur dioxide emissions in regards to both per capita a GDP per capita (5).

$$
\log (E / P)=\alpha+\beta^{*} \log (G D P / P)^{2}+u
$$

where $E$ represents the emissions, $P$ is the population, $\alpha$ and $\beta$ are a constant and a slope coefficient of the estimated curve, respectively (Hercegová et al. 2012).

Chuku (2011) conducted an empirical analysis for Nigeria through utilization of function (6).

$$
(E / P)=\alpha_{0}+\alpha_{1 t}+\beta_{1}(G D P / P)_{t}+\beta_{2}(G D P / P)_{t}^{2}+\beta_{3}(G D P / P)_{t}^{3}+\gamma X_{t}+\mu_{t}
$$


where $E$ is environmental pollution expressed as the volume of carbon dioxide emissions, $E / P$ is the carbon dioxide emissions per capita, $P$ is the size of the population, GDP/P is the real GDP per capita, $X_{t}$ is a vector of variables that often influence the environment, and $t$ is the deterministic trend as a proxy for technical progress (Chuku, 2011).

Khyareh (2012) researched the possible existence of an environmental Kuznets curve for carbon dioxide emissions in Iran. Just as Shafik et al (1992), Khyareh estimated the parameters of three functional forms (7), (8), (9), where $T$ is time (Khyareh, 2012).

$$
\begin{gathered}
C O_{2}=\alpha_{1}+\alpha_{2}(G D P)_{t}+\alpha_{3} T+\alpha_{4}+T+\varepsilon_{i t} \\
C O_{2}=\beta_{1}+\beta_{2}(G D P)_{t}+\beta_{2}(G D P)_{t}^{2}+\beta_{4} T+\beta_{4} T^{2}+\varepsilon_{2 t} \\
C O_{2}=\gamma_{1}+\gamma_{2}(G D P)_{t}+\gamma_{3}(G D P)_{t}^{2}+\gamma_{4}(G D P)^{3}+\gamma_{5} T+\gamma_{6} T^{2}+\varepsilon_{3 t}
\end{gathered}
$$

Similar to Shafik et al (1992), we estimated the parameters of three functional forms that express the relationship between the dependent and independent variables. The dependent variable was the volume of individual greenhouse gas emissions per capita, the independent variables were the GDP (adjusted for inflation) in 2005 US dollars in logarithmic form, in a logarithm of the variable squared, and in a logarithm of the variable cubed. We estimated the parameters of three functional forms: linear (10), quadratic (11) and cubic (12)

$$
\begin{gathered}
\text { ghgtpc }=a_{1}+a_{2} \ln (Y)+\varepsilon_{1} \\
\text { ghgtpc }=b_{1}+b_{2} \ln (Y)+b_{3} \ln \left(Y^{2}\right)+\varepsilon_{2} \\
\text { ghgtpc }=c_{1}+c_{2} \ln (Y)+c_{3} \ln \left(Y^{2}\right)+c_{4} \ln \left(Y^{3}\right)+\varepsilon_{3}
\end{gathered}
$$

where ghgtpc is the total volume of greenhouse gas emissions per capita, $Y$ is the real GDP per capita, $\ln$ is the natural logarithm and $\varepsilon$ is the error. In other estimates we have substituted the specifically selected greenhouse gases for ghgtpc. Table 1 below gives an overview of the variables and data, Table 2 provides an overview of basic statistics of the individual variables.

Table 1

Variables and Data

\begin{tabular}{|l|l|l|}
\hline \multicolumn{1}{|c|}{$\begin{array}{c}\text { Variable } \\
\text { Label }\end{array}$} & \multicolumn{1}{c|}{ Content } & \multicolumn{1}{c|}{ Source } \\
\hline \multicolumn{1}{|c|}{1} & \multicolumn{1}{c|}{ 2 } & \multicolumn{1}{c|}{3} \\
\hline ghgtpc & greenhouse gasses emissions per capita & own calculation based on the OECD data \\
\hline coxpc & carbon dioxide emissions per capita & own calculation based on the OECD data \\
\hline mtnpc & methane emissions per capita & own calculation based on the OECD data \\
\hline noxpc & nitrous oxide emissions per capita & own calculation based on the OECD data \\
\hline hfcpc & hydrofluorocarbon emissions, per capita & own calculation based on the OECD data \\
\hline pfc & perfluorcarbons emissions, per capita & own calculation based on the OECD data \\
\hline
\end{tabular}




\begin{tabular}{|l|l|l|}
\hline \multicolumn{1}{|c|}{1} & \multicolumn{1}{|c|}{2} & \multicolumn{1}{|c|}{3} \\
\hline soxpc & sulphur hexafluoride emissions, per capita & own calculation based on the OECD data \\
\hline gdppcc2005us & GDP per capita (constant 2005 US\$) & World Bank \\
\hline Y & GDP per capita (constant 2005 US\$) & World Bank \\
\hline $\ln Y$ & $\begin{array}{l}\text { logarithm GDP per capita (constant US\$) } \\
\text { own calculation based on the World Bank } \\
\text { data }\end{array}$ \\
\hline lnYCB & $\begin{array}{l}\text { logarithm of GDP per capita (constant US\$) } \\
\text { square }\end{array}$ & $\begin{array}{l}\text { own calculation based on the World Bank } \\
\text { data }\end{array}$ \\
\hline fdintinfpr & $\begin{array}{l}\text { logarithm of GDP per capita (constant US\$) } \\
\text { cube }\end{array}$ & $\begin{array}{l}\text { own calculation based on the World Bank } \\
\text { data }\end{array}$ \\
\hline
\end{tabular}

Note: 1) LULUCF stands for Land Use, Land Use Change and Forestry. 2) All types of greenhouse gasses are measured in thousands of tons and do not include LULUCF.

Table 2

Review of main statistics involved in models

\begin{tabular}{|l|c|c|c|c|c|}
\hline \multicolumn{1}{|c|}{ Variable } & Obs & Mean & Std. Dev. & Min & Max \\
\hline gdppcc2005us & 23 & 10330.57 & 2732.343 & 6821.645 & 14997.6 \\
\hline $\operatorname{lnY}$ & 23 & 9.210403 & .2587082 & 8.827856 & 9.615645 \\
\hline $\operatorname{lnYSQ}$ & 23 & 84.89554 & 4.782413 & 77.93105 & 92.46064 \\
\hline $\operatorname{lnYCB}$ & 23 & 783.1054 & 66.3407 & 687.9641 & 889.0687 \\
\hline ghgtpc & 22 & .0097502 & .0011815 & .0081121 & .0135458 \\
\hline coxpc & 22 & .0081733 & .0010653 & .0066073 & .0114631 \\
\hline mtnpc & 22 & .0007965 & .0000494 & .0007153 & .0009114 \\
\hline noxpc & 22 & .0007386 & .0001307 & .0005575 & .0011985 \\
\hline pfcpc & 22 & .0000132 & .0000165 & $2.16 \mathrm{e}-06$ & .0000512 \\
\hline soxpc & 22 & $2.25 \mathrm{e}-06$ & $1.23 \mathrm{e}-06$ & $5.85 \mathrm{e}-09$ & $3.84 \mathrm{e}-06$ \\
\hline
\end{tabular}

At the beginning of the analysis we calculated the pair-wise correlation coefficients which are shown in the correlation matrix in table 3. Estimates of the parameters for linear, quadratic, and cubic functions for the individual greenhouse gases are shown in table 4. Based on the calculations of the parameters, their p-values, and the coefficients of determination, it can be concluded that there is a statistically significant negative linear relationship between total greenhouse gas emissions and the growth of GDP per capita.

Estimated parameters of the quadratic and cubic functions do not indicate a different type of functional dependence, and from the graph it is clear that the existence of an environmental Kuznets curve is not confirmed. Based on the data above, we can also make a similar conclusion in the cases of carbon dioxide, nitrous oxide, and perfluorocarbons. In the case of sulphur hexafluoride, economic growth and development reflected in the growth of income per capita led to a sharp increase in emissions. In regards to methane neither a linear nor a cubic relationship was confirmed among the researched variables, and this is the only greenhouse gas where estimates suggest the presence of an environmental Kuznets curve. 
Table 3

Correlation coefficients between GDP per capita and emissions of selected greenhouse gasses per capita in Slovakia

\begin{tabular}{|l|c|c|c|c|c|c|c|c|c|c|}
\hline & $\begin{array}{c}\text { gdppc- } \\
\text { c2005us }\end{array}$ & $\ln Y$ & $\ln Y S Q$ & $\ln Y C B$ & ghgtpc & coxpc & mtnpc & noxpc & pfcpc & soxpc \\
\hline & & & & & & & & & & \\
\hline gdppcc2005us & 1.0000 & & & & & & & & & \\
\hline $\ln Y$ & 0.9950 & 1.0000 & & & & & & & & \\
\hline $\ln Y S Q$ & 0.9960 & 0.9999 & 1.0000 & & & & & & & \\
\hline $\ln Y C B$ & 0.9970 & 0.9998 & 0.9999 & 1.0000 & & & & & & \\
\hline ghgtpc & -0.5981 & -0.5894 & -0.5907 & -0.5920 & 1.0000 & & & & & \\
\hline coxpc & -0.6433 & -0.6376 & -0.6387 & -0.6396 & 0.9971 & 1.0000 & & & & \\
\hline mtnpc & 0.1942 & 0.2672 & 0.2592 & 0.2512 & 0.1041 & 0.0575 & 1.0000 & & & \\
\hline noxpc & -0.3824 & -0.3696 & -0.3713 & -0.3729 & 0.9172 & 0.8920 & 0.0968 & 1.0000 & & \\
\hline pfcpc & -0.5316 & -0.5704 & -0.5663 & -0.5622 & 0.8468 & 0.8568 & -0.2265 & 0.7531 & 1.0000 & \\
\hline soxpc & 0.8119 & 0.8345 & 0.8324 & 0.8301 & -0.8513 & -0.8813 & 0.2251 & -0.6661 & -0.8907 & 1.0000 \\
\hline
\end{tabular}

Source: authors own calculation

The conclusions from the regression analysis confirmed the graphical representations of individual relationships. In figure 5, scatter-plots are shown in individual panels and their lines of regression were estimated using a bandwidth of 0.8 . The line of best fit shows a monotonically decreasing trend when comparing the total greenhouse gas emissions of carbon dioxide and nitrous oxide with the evolution of real GDP per capita. This suggests that economic growth and an increase in income per capita led to reductions in emissions of the selected greenhouse gases. The decline of perfluorocarbons with the growth of income per capita is significant. In the case of sulphur hexafluoride neither economic growth nor an increase in income per capita led to a decrease in emissions, but instead led to an increase. Only in the case of methane does the smoothed regression line indicate the ideal shape, similar to the Kuznets curve. In this case, levels of methane in the Slovak Republic first rose with the growth of GDP per capita, while methane emissions later declined in connection with further economic growth reflected in income per capita. 
Table 4

Results of regression analysis

\begin{tabular}{|c|c|c|c|c|c|c|}
\hline $\begin{array}{l}\text { Dependent } \\
\text { variable }\end{array}$ & $\begin{array}{l}\text { constant } \\
\text { ( } p \text {-value) }\end{array}$ & $\begin{array}{c}Y \\
(p \text {-value) }\end{array}$ & $\begin{array}{c}\ln Y^{2} \\
(p \text {-value })\end{array}$ & $\begin{array}{c}\ln Y^{3} \\
(p \text {-value })\end{array}$ & $R^{2}$ & $\begin{array}{l}\text { Number of } \\
\text { observations }\end{array}$ \\
\hline 1 & 2 & 3 & 4 & 5 & 6 & 7 \\
\hline \multirow[t]{3}{*}{ ghgtpc } & $\begin{array}{c}.035469 \\
(0.000)\end{array}$ & $\begin{array}{c}-.002798 \\
(0.004)\end{array}$ & & & 0.3474 & 22 \\
\hline & $\begin{array}{c}-.2034106 \\
(0.577)\end{array}$ & $\begin{array}{c}.0489993 \\
(0.535)\end{array}$ & $\begin{array}{c}-.0028059 \\
(0.512)\end{array}$ & & 0.3623 & 22 \\
\hline & $\begin{array}{c}-8.996315 \\
(0.633)\end{array}$ & $\begin{array}{c}2.91707 \\
(0.634)\end{array}$ & $\begin{array}{c}-.3145138 \\
(0.637)\end{array}$ & $\begin{array}{c}.0112877 \\
(0.640)\end{array}$ & 0.3702 & 22 \\
\hline \multirow[t]{3}{*}{$\operatorname{coxpc}$} & $\begin{array}{c}.0332623 \\
(0.000)\end{array}$ & $\begin{array}{c}-.0027294 \\
(0.001)\end{array}$ & & & 0.4066 & 22 \\
\hline & $\begin{array}{c}-.132655 \\
(0.673)\end{array}$ & $\begin{array}{c}.0332471 \\
(0.625)\end{array}$ & $\begin{array}{c}-.0019489 \\
(0.597)\end{array}$ & & 0.4155 & 22 \\
\hline & $\begin{array}{c}-8.304134 \\
(0.609) \\
\end{array}$ & $\begin{array}{c}2.698621 \\
(0.610) \\
\end{array}$ & $\begin{array}{c}-.2916273 \\
(0.612) \\
\end{array}$ & $\begin{array}{c}.0104899 \\
(0.615) \\
\end{array}$ & 0.4239 & 22 \\
\hline \multirow[t]{3}{*}{ mtnpc } & $\begin{array}{l}.000309 \\
(0.441)\end{array}$ & $\begin{array}{l}.000053 \\
(0.229)\end{array}$ & & & 0.0714 & 22 \\
\hline & $\begin{array}{c}-.0578756 \\
(0.000)\end{array}$ & $\begin{array}{c}.0126695 \\
(0.000)\end{array}$ & $\begin{array}{c}-.0006834 \\
(0.000)\end{array}$ & & 0.5788 & 22 \\
\hline & $\begin{array}{l}.3471551 \\
(0.586) \\
\end{array}$ & $\begin{array}{c}-.1194435 \\
(0.565) \\
\end{array}$ & $\begin{array}{c}.0136749 \\
(0.545) \\
\end{array}$ & $\begin{array}{c}-.0005199 \\
(0.525)\end{array}$ & 0.5884 & 22 \\
\hline \multirow[t]{3}{*}{ noxpc } & $\begin{array}{c}.0025233 \\
(0.021)\end{array}$ & $\begin{array}{c}-.0001942 \\
(0.090)\end{array}$ & & & 0.1366 & 22 \\
\hline & $\begin{array}{c}-.0301964 \\
(0.515)\end{array}$ & $\begin{array}{c}.0069006 \\
(0.492)\end{array}$ & $\begin{array}{c}-.0003843 \\
(0.480)\end{array}$ & & 0.1596 & 22 \\
\hline & $\begin{array}{c}-1.168595 \\
(0.625)\end{array}$ & $\begin{array}{c}.3782235 \\
(0.627)\end{array}$ & $\begin{array}{c}-.0407405 \\
(0.630)\end{array}$ & $\begin{array}{c}.0014614 \\
(0.634)\end{array}$ & 0.1704 & 22 \\
\hline \multirow[t]{3}{*}{ pfepc } & $\begin{array}{c}.0003614 \\
(0.004)\end{array}$ & $\begin{array}{c}-.0000379 \\
(0.006)\end{array}$ & & & 0.3254 & 22 \\
\hline & $\begin{array}{c}.0102683 \\
(0.039) \\
\end{array}$ & $\begin{array}{c}-.002186 \\
(0.042)\end{array}$ & $\begin{array}{c}.0001164 \\
(0.045)\end{array}$ & & 0.4568 & 22 \\
\hline & $\begin{array}{c}.0512748 \\
(0.833)\end{array}$ & $\begin{array}{c}-.0155615 \\
(0.845)\end{array}$ & $.00157(0.856)$ & $\begin{array}{c}-.0000526 \\
(0.866)\end{array}$ & 0.4577 & 22 \\
\hline \multirow[t]{3}{*}{ soxpc } & $\begin{array}{c}-.0000356 \\
(0.000)\end{array}$ & $\begin{array}{c}4.11 \mathrm{e}-06 \\
(0.000)\end{array}$ & & & 0.6964 & 22 \\
\hline & $\begin{array}{c}-.0004164 \\
(0.100)\end{array}$ & $\begin{array}{c}.0000867 \\
(0.114)\end{array}$ & $\begin{array}{c}-4.47 \mathrm{e}-06 \\
(0.131)\end{array}$ & & 0.7317 & 22 \\
\hline & $\begin{array}{c}-.0060216 \\
(0.635)\end{array}$ & $\begin{array}{l}.001915 \\
(0.643)\end{array}$ & $\begin{array}{c}-.0002032 \\
(0.651)\end{array}$ & $\begin{array}{c}7.20 \mathrm{e}-06 \\
(0.658)\end{array}$ & 0.7347 & 22 \\
\hline
\end{tabular}

Notes: Y represents GDP per capita, constant 2005 US dollars

Source: authors own calculation 

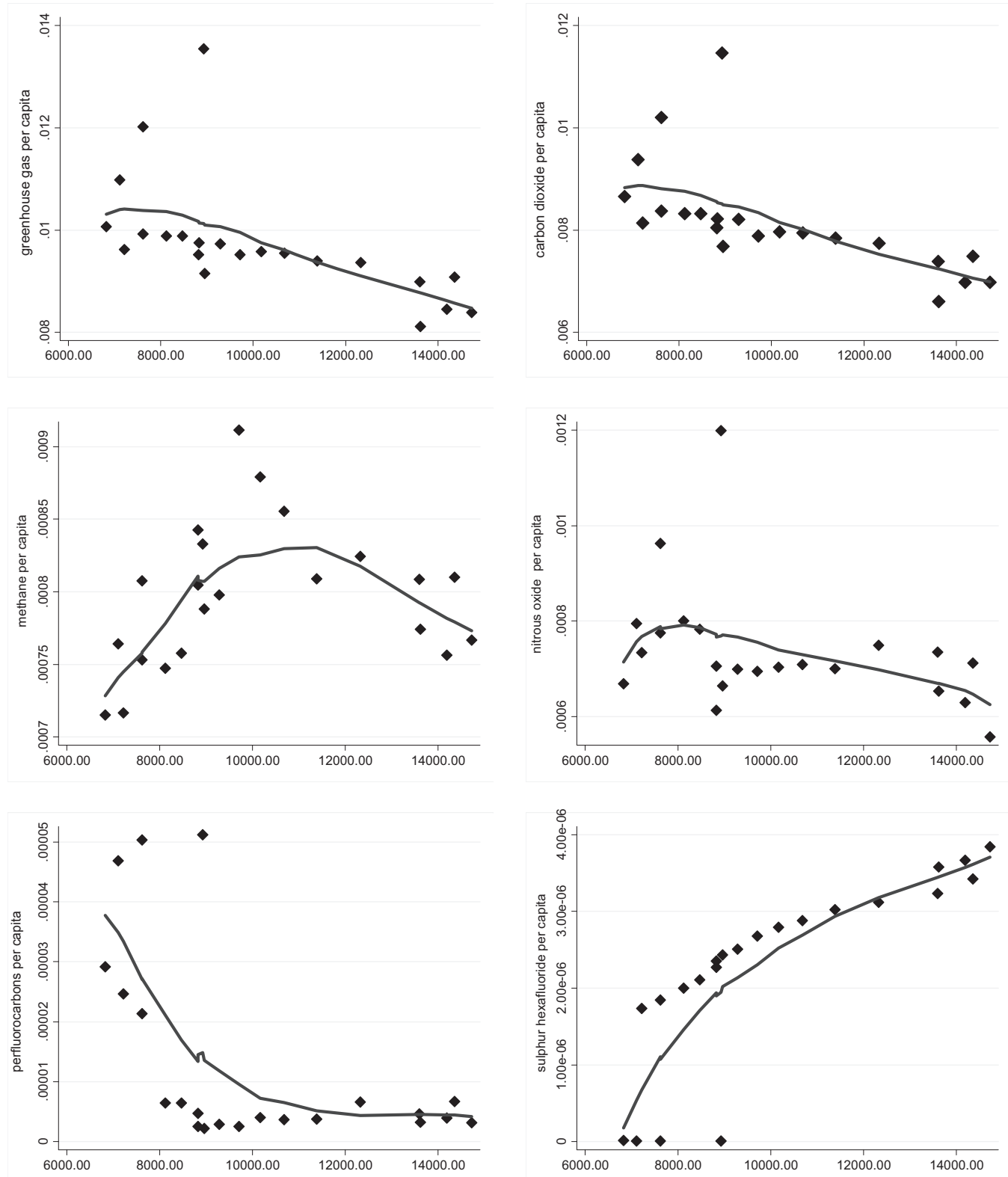

Gross domestic product per capita, constant 2005 US dollars

Figure 5. Scatter plots

Source: author's own compilation 


\section{TESTING POLLUTION HAVEN HYPOTHESIS IN SLOVAKIA}

In this section we examine whether the hypothesis of the Slovak Republic as a pollution haven can be confirmed through analyzing emissions of individual greenhouse gases. Specifically, we are interested in whether there is a causal relationship between FDI inflows and the volume of greenhouse gas emissions in the Slovak republic, and what direction this relationship takes. Direct foreign investments are measured by the amount of net inflows of direct foreign investments as a percentage of GDP. The data are from the World Bank database. Information concerning other variables is given in tables 1 and 2.

In this econometric analysis, we proceeded by first calculating the pairwise correlation coefficients of FDI, listed in table 5. These show a relatively high/strong mutual link between foreign investments and greenhouse gas emissions, showing a negative relationship, with the exception of sulphur hexafluoride.

Table 5

Correlation matrix

\begin{tabular}{|l|c|c|c|c|c|c|c|c|}
\hline & fdintbop & fdintinfpr & ghgtpc & coxpc & mtnpc & noxpc & pfcpc & soxpc \\
\hline fdintbop & 1.0000 & & & & & & & \\
\hline fdintinfpr & -0.8188 & 1.0000 & & & & & & \\
\hline ghgtpc & -0.8784 & 0.6287 & 1.0000 & & & & & \\
\hline coxpc & -0.8664 & 0.6177 & 0.9938 & 1.0000 & & & & \\
\hline mtnpc & -0.8302 & 0.7505 & 0.8918 & 0.8459 & 1.0000 & & & \\
\hline noxpc & -0.6560 & 0.4254 & 0.7633 & 0.6885 & 0.8876 & 1.0000 & & \\
\hline pfcpc & -0.7736 & 0.5727 & 0.6566 & 0.6031 & 0.7363 & 0.7203 & 1.0000 & \\
\hline soxpc & 0.6309 & -0.4089 & -0.8766 & -0.8427 & -0.8754 & -0.8770 & -0.4653 & 1.0000 \\
\hline
\end{tabular}

However, the correlation coefficients cannot be interpreted as a causal relationship between variables. They do not provide enough information about whether the change in emission levels for individual greenhouse gases in past periods significantly influenced the future FDI inflows into the Slovak Republic. For this reason, we analyze the causal relationship between researched variables through the Granger causality test. A prerequisite for testing Granger causality is the stationarity of a time series. Therefore, in the first step we tested the time series for the presence of a unit root.

Granger causality between variables is significantly affected by the number of delays in the model. Therefore, in the second step we determined the correct delay. In the third step we estimated the parameters of autoregressive models and their significance by the vector autoregressive method. In the last step, we tested for the existence and the direction of a causal relationship between FDI and individual greenhouse gases.

A prerequisite for the application of the Granger causality test is stationarity of the time series, where the time series is stationary if it has no unit root. We tested the presence of a unit root in the times series of variables though the test statistic of an adapted Dickey-Fuller test, ADF test. The individual variables (the net inflows of direct foreign investments and individual greenhouse gas emissions) were tested first for the presence of a unit root null and the first differential in selected cases. The results of testing the time series for the presence of a unit root are in table 6 .

Stationarity for fdintinfpr was also tested through the ADF test. The null hypothesis of the ADF test is as follows: the test variable (the time series) has a unit root, meaning that it is not stationary. The rule of thumb is, if the value of the calculated ADF statistic is larger than the table of critical values for a significance 
level of $1 \%, 5 \%$ or $10 \%$, then the null hypothesis is rejected. In our case, the value of the ADF statistic for fdintinfpr null is greater than the table of critical values. We therefore reject the null hypothesis that the time series has a unit root and we accept the alternative hypothesis that the time series does not have a unit root, meaning that the time series is stationary. This variable thus qualifies for the application of the Granger causality test.

Table 6

ADF test results

\begin{tabular}{|c|c|c|c|c|c|c|c|}
\hline \multirow{2}{*}{ variable } & \multirow{2}{*}{ level } & \multirow{2}{*}{$\begin{array}{c}\text { Test statistic } \\
\mathrm{Z}(\mathrm{t})\end{array}$} & \multirow{2}{*}{$\begin{array}{l}\text { McKinon } \\
\text { approximate p- } \\
\text { value for } Z(t)\end{array}$} & \multicolumn{3}{|c|}{ Critical value on significance level } & \multirow{2}{*}{$\begin{array}{c}\text { Presence of unit } \\
\text { root } \\
(+),(-)\end{array}$} \\
\hline & & & & $1 \%$ & $5 \%$ & $10 \%$ & \\
\hline fdintinfpr & $(0)$ & $-4,928$ & 0,0000 & $-3,750$ & $-3,000$ & $-2,630$ & $(-)$ \\
\hline fdintinfer & $(0)$ & $-2,381$ & 0,1473 & $-3,750$ & $-3,000$ & $-2,630$ & $(+)$ \\
\hline ghgtpc & $(0)$ & $-5,295$ & 0,0000 & $-3,750$ & $-3,000$ & $-2,630$ & $(-)$ \\
\hline $\operatorname{coxpc}$ & $(0)$ & $-4,794$ & 0,0001 & $-3,750$ & $-3,000$ & $-2,630$ & $(-)$ \\
\hline noxpc & $(0)$ & $-5,434$ & 0,0000 & $-3,750$ & $-3,000$ & $-2,630$ & $(-)$ \\
\hline pfpcpc & $(0)$ & $-2,989$ & 0,0359 & $-3,750$ & $-3,000$ & $-2,630$ & $(+) /(-)$ \\
\hline pfpcpc & (1) & $-3,935$ & 0,0018 & $-3,750$ & $-3,000$ & $-2,630$ & $(-)$ \\
\hline mtnpc & $(0)$ & $-1,915$ & 0,3252 & $-3,750$ & $-3,000$ & $-2,630$ & $(+)$ \\
\hline mtnpc & (1) & $-2,046$ & 0,2669 & $-3,750$ & $-3,000$ & $-2,630$ & $(+)$ \\
\hline soxpc & (0) & $-1,377$ & 0,5933 & $-3,750$ & $-3,000$ & $-2,630$ & $(+)$ \\
\hline soxpc & (1) & $-1,741$ & 0,4101 & $-3,750$ & $-3,000$ & $-2,630$ & $(+)$ \\
\hline
\end{tabular}

In contrast, the time series for the net FDI inflows at current prices, fdintinfcr, does not meet the stationarity requirement, because the test for the presence of the unit root null indicated the presence of a unit root. Without further adjustments it is not possible to use this variable to verify Granger causality.

Through testing for the presence of a unit root null in the time series we found that only the time series for the variables $g h g t p c$, $\operatorname{coxp} c$, noxpc, and fdintinfpr are stationary. Conversely, $p f c p c$, soxpc, $\operatorname{mtn} p c$ and even fdintinfcr are non-stationary, i.e. have unit roots. Therefore, we chose only the stationary variables, i.e. a time series of the percentage of FDI to GDP, total greenhouse gas emissions of carbon dioxide and nitrous oxide, for testing Granger causality. We performed the analysis for the period 1993 to 2011.

The result of the Granger causality test between variables is significantly influenced by the number of delays, which are to be applied in the vector autoregression analysis (VAR). Therefore, we first conducted a preliminary vector auto regression analysis with the selected variables derived from verified Granger tests. Using the statistical criteria, we then made the selection of the optimal length of the delay. Econometric science offers several criteria for the identification of the correct length delay, such as the Akaike information criterion (AIC), the Hannan-Quinn information criterion (HQIC), and the Schwarz Bayesian information criterion (SBIC). In order to choose the correct number of delays to be applied in the Granger causality test we calculated the values of both test statistics for the FPE, AIC, HQIC, and SBIC. The resulting values for each criterion are in table 7 . 
Table 7

Values of test criterions to select the best lag

\begin{tabular}{|c|c|c|c|c|c|c|c|c|}
\hline lag & $L L$ & $L R$ & $d f$ & $p$ & $F P E$ & $A I C$ & $H Q I C$ & $S B I C$ \\
\hline 0 & 213,793 & & & & $7,1 \mathrm{e}-24$ & $-41,9585$ & $-42,0913$ & $-41,8375$ \\
\hline 1 & 248,901 & 70,217 & 16 & 0,000 & $2,3 \mathrm{e}-25$ & $-45,7802$ & $-46,4441$ & $-45,175$ \\
\hline 2 & - & - & 16 & - & $-1,4 \mathrm{e}-69^{*}$ & - & - & - \\
\hline 3 & 1442,52 & - & 16 & - & - & $-280,504$ & $-281,832$ & $-279,294$ \\
\hline 4 & 1464,47 & $43,9^{*}$ & 16 & 0,000 & - & $-284,894 *$ & $-286,222^{*}$ & $-283,684 *$ \\
\hline $\begin{array}{c}\text { Endogenous: } \\
\text { fdintin- } \\
\text { fpr gdgtpc } \\
\text { coxpc noxpc } \\
\text { Exogenous: } \\
\text { cons }\end{array}$ & & & & & & & & \\
\hline
\end{tabular}

For the Granger causality test we chose the number of delays for which the calculated value of the test statistic is the lowest. Values of the AIC, HQIC, and SBIC criteria indicate the suitability of four lags, the FPE value indicates the suitability of two lags. The calculated values for the majority of the criteria suggest that it is best to select four lags when testing Granger causality.

In the next step we performed the vector regression analysis of the selected variables and we chose four lags, staying consistent with the AIC, HQIC, and SBIC criteria.

Table 8

Vector autoregression analysis - results

fdintinfpr vs ghgtpc

$$
\begin{gathered}
\text { Coefficient } \\
(\mathrm{P}>|\mathrm{t}|)
\end{gathered}
$$

fdintinfpr

$\begin{array}{cc}\text { fdintinfpr } & \\ \text { L1 } & .2037449 \\ & (0.625) \\ \text { L2 } & 2.576976 \\ & (0.090) \\ \text { L3 } & -2.477824 \\ & (0.092) \\ \text { L4 } & -.8153787 \\ & (0.126) \\ \text { ghgtpc } & -834.1487 \\ \text { L1 } & (0.567) \\ & -9157.679 \\ \text { L2 } & (0.080) \\ & 3962.219 \\ \text { L3 } & (0.338)\end{array}$

fdintinfpr vs coxpc

Coefficient

$(\mathrm{P}>|\mathrm{t}|)$

fdintinfpr

fdintinfpr

$$
\text { L1 }
$$

.6456568

$(0.432)$

L2 2.466356

$(0.189)$

L3 -3.029108

(0.148)

L4 -1.007756

( 0.211)

coxpc

$$
\begin{array}{cc}
\text { L1 } & -1816.687 \\
& (0.652)
\end{array}
$$

L2 -9738.154

(0.151)

L3 3464.076

(0.670) fdintinfpr vs noxpc

Coefficient $(\mathrm{P}>|\mathrm{t}|)$

fdintinfpr

fdintinfpr

L1 .2009571

(0.892)

L2 1.168047

(0.607)

L3 -1.189962

(0.368)

L4 -.4386607 (0.630)

noxpc

L1 -7231.53

( 0.938)

L2 -33853.12

(0.733)

L3 -4691.96

(0.962) 


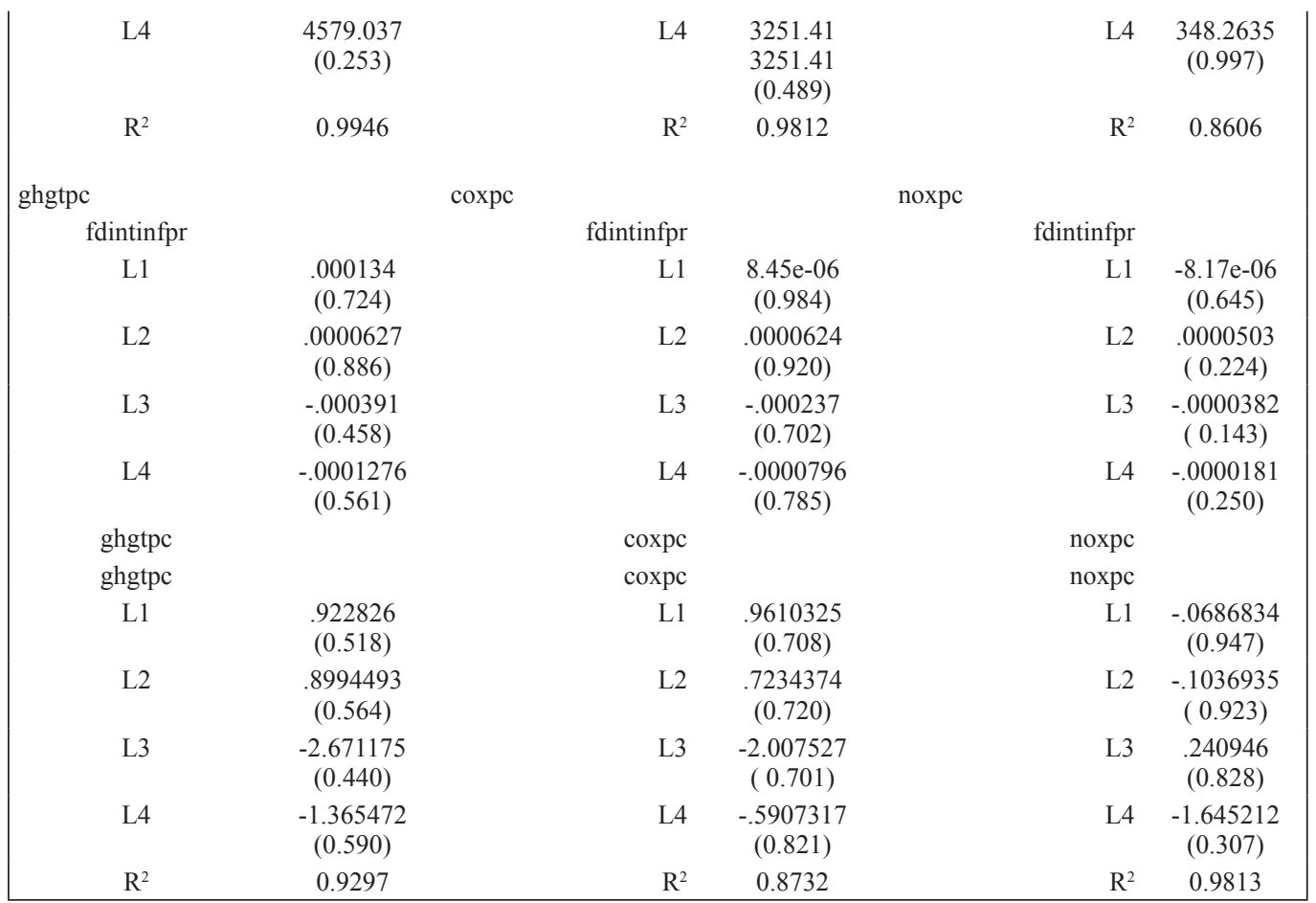

Source: author's own calculation

Next, we verify the Granger causality between the net FDI inflows as a percentage of GDP and selected greenhouse gas emissions per capita in the Slovak Republic.

The Granger causality test has the null hypothesis that the delay variable does not cause changes in the second variable. If the p-value is greater than $5 \%$, we cannot reject the null hypothesis and we accept the hypothesis that the delay variable does not share a Granger causal relationship with the second variable. This means that based on the past development of one variable it is not possible to predict the future development of the second variable. The results of the verification of Granger causality between net FDI inflows and selected greenhouse gas emissions are in table 9.

Table 9

Granger causality test results

\begin{tabular}{|l|c|c|c|c|c|}
\hline \multicolumn{1}{|c|}{ Equation } & Excluded & F & df & df_r & Prob > F \\
\hline fdintinfpr & ghgtpc & 29.728 & 4 & 1 & 0.1366 \\
\hline ghgtpc & fdintinfpr & .57021 & 4 & 1 & 0.7440 \\
\hline fdintinfpr & coxpc & 8.3173 & 4 & 1 & 0.2537 \\
\hline coxpc & fdintinfpr & .22694 & 4 & 1 & 0.8962 \\
\hline fdintinfpr & noxpc & .90777 & 4 & 1 & 0.6469 \\
\hline noxpc & fdintinfpr & 5.4066 & 4 & 1 & 0.3107 \\
\hline
\end{tabular}


First we estimated the parameters of the vector auto regression equations for the relationship between carbon dioxide and the percentage of net FDI inflows to GDP. We then applied the Granger causality test. The existence of causality between FDI inflows and the volume of carbon dioxide emissions per capita was not confirmed in either direction. Net FDI inflows into the Slovak Republic as a percentage of GDP do not share a causal relationship with the amount of carbon dioxide emissions in the present period and the past four years. By the same method we examine the potential causal relationship between FDI inflows and greenhouse gas emissions per capita in the present period and the four previous periods. We estimated the parameters of the model of vector regression analysis and then we applied the Granger causality test.

\section{CONCLUSION}

A statistically significant linear negative relationship between total greenhouse gas emissions and growth of real GDP per capita was confirmed. The estimated parameters of the quadratic and cubic functional forms do not indicate a different kind of functional dependence, and from the graph it is clear that the existence of an environmental Kuznets curve was not confirmed. It is also possible to make the same conclusion in the relationships of carbon dioxide, nitrous oxide, and perfluorocarbons emissions and economic growth (GDP per capita).

In the case of sulphur hexafluoride, economic growth and development reflected in the growth of income per capita leads to a sharp increase in emissions. Only in the case of methane was neither a linear nor a cubic relationship confirmed between the variables of interest. A quadratic relationship was confirmed suggesting that this is the only type of greenhouse gas where estimates indicate a relationship which follows an environmental Kuznets curve.

We examined the possible causal relationship between net FDI inflows and emissions of select greenhouse gases. The objective was to verify whether the volumes of select greenhouse gas emissions are a significant determinant of FDI inflows into the Slovak Republic. The parameters of the coefficients of three models estimated by vector autoregression analysis are not statistically significant. Based on the calculated values of the Granger causality test we conclude that the volume of greenhouse gas emissions per capita in the present period and in any of the previous four periods has no effect on the amount of net FDI inflows as a percentage of GDP in the Slovak Republic.

The conclusions of this empirical analysis allow us to conclude that with economic growth in the Slovak republic, the quality of the environment improves, and there is no evidence that the Slovak Republic lowers environmental standards in order to increase its competitiveness and attract foreign investment.

\section{REFERENCES}

Bewer, M. et al. 2008. Poverty and Inequality in the UK: 2007. IFS Briefing Note. 2008, 73.

Chuku, A. 2011. Economic Ddevelopment and Environmental Quality in Nigeria: Is there an Environmental Kuznets Curve? MPRA Paper. January 2011, No. 30195.

Cole, M. A., 2004. Trade, the Pollution Haven Hypothesis and the Environmental Kuznets Curve: Examining the Linkages. Ecological Economics, 48(1), pp. 71-88.

Cole, M. A., Elliot, R. J. R. \& Frederiksson, P. G., 2006. Endogenous Pollution Havens: Does FDI Influence Environmental Regulations? Scandinavian Journal of Economics, 108(1), pp. 157-178.

Deacon, R. T. \& Norman, C. S., 2006. Does the Environmental Kuznets Curve Describe How individual Countries Behave? Land Economics, May, 82(2), pp. 291-315. 
Eskeland, G. S., Harrison, A. E. 1997. Moving to Greener Pastures? Multinationals and the Pollution Haven Hypothesis. Working Paper. 1997, 1744.

Gale, L. R., 1998. The Empirical Relationship Between Trade, Growth and the Environment. International Review of Economics and Finance, 7(1), pp. 53-61.

Grossman, G. M., Krueger, A. B. 1991. Environmental Impact of a North American Free Trade Agreement. NBER Working Paper. 1991, 3914.

Hercegová, K. a Strielkowski, W. 2012. New Evidence for the Environmental Kuznets Curve for Sulfur Dioxide Emissions: A Case Study of the Czech Republic. Social and Natural Sciences. 2012, 2.

Khyareh, M. M. 2012. The Validity of Environemntal Kuznets Curve in the Case of Iran. International Journal of Economics and Management Engineering (IJEME). August 2012, Vol 2, Issue 3, s. 129-131.

Kuznets, S. 1955. Economic Growth and Income Inequality. American Economic Review. 1955, Vol. 45, s. 1-28.

Lieb, C. M., 2003. The Environmental Kuynets Curve - A Survey of the Empirical Evidence and of Possible Causes. University of Heidelberg Department of Economics Discussion paper Series, Issue 391.

Neumayer, E. 2001. Pollution Havens: An Analysis of Policy Options for Dealing with an Elusive Phenomenon. Journal of Environment and Development. June 2001, 2, s. 147-177.

OECD. 2013. The OECD Environment Statistics. www.oecd.org

Panayoutou, T. 1999. Environmental Degradation an Inevitable Consequence Oo Economic Growth: Tunneling through the Environmental Kuznets Curve. Ecological Economics. 1999, 1, s. 89-109.

Shafik, N. and Bandyopadhyay, S.. 1992. Economic Growth and Environmental Quality. Policy Research Working Papers. June 1992.

Stern, D. 2004. Environmental Kuznets curve. Encyclopedia of Energy. Elsevier Inc, 2004, Vol. 2.

Stokey, N. L., 1998. Are There Limits to Growth? International Economic Review, 39(1), pp. 1-31.

Unruh, G. C. \& Moomaw, W. R., 1998. An Alternative Analysis of Apparent EKC-type transitions. Ecological Economics, Vol 25, pp. 221-229.

Yandle, B., Vijayaraghavan, M. \& Bhattarai, M., 2002. The Environmental Kuznets Curve. A Primer. PERC Research Study, Issue May. 